\title{
Chromosomes of Bromus auleticus Trin. ex Nees (Poaceae)
}

\author{
Gilmar Efrem Martinello ${ }^{1}$ and Maria Teresa Schifino-Wittmann ${ }^{2}$ \\ ${ }^{1}$ Universidade Estadual do Rio Grande do Sul, Cachoeira do Sul, RS, Brazil. \\ ${ }^{2}$ Universidade Federal do Rio Grande do Sul, Faculdade de Agronomia, \\ Departamento de Plantas Forrageiras e Agrometeorologia, Porto Alegre, RS, Brazil.
}

\begin{abstract}
The chromosome number of 14 accessions of Bromus auleticus Trin. ex Nees, native of Rio Grande do Sul, was $2 n=6 x=42$, same ploidy level found in other South-American Bromus species. Its chromosomes were metacentric or submetacentric, ranging from ca. $4 \mu \mathrm{m}$ to ca. $8 \mu \mathrm{m}$ in length. Up to two satellite-bearing chromosome pairs were sometimes observed. However, as already reported for other species, the high symmetry and homogeneity of the karyotypes made it difficult to detect possible intraspecific differences.
\end{abstract}

Key words: Bromus auleticus, chromosome numbers, native forages.

Received: February 26, 2003; Accepted: May 29, 2003.

\section{Introduction}

The genus Bromus comprises more than 100 annual and perennial species (Mabberley, 1997) distributed around the world, typically cool-season grasses, varying greatly in adaptation and use, and including some important forage and range species, such as the perennials $B$. inermis, $B$. anomalus, B. pumpellianus, B. catharticus, and the annuals $B$. mollis and $B$. rigidus, among others (Carlson and Newell, 1985).

Chromosome numbers vary from $2 n=14$ to $2 n=84$, most of the species being diploid $(2 n=14)$ or tetraploid $(2 n$ = 28) (Federov, 1969). Chromosome size may be very different among species (Armstrong, 1983; Schifino and Winge, 1983). Ploidy levels may vary within the same species, as in B. diandrus and B. sterilis (Oja and Laarmann, 2002). The chromosome complements consist mainly of chromosomes resembling each other in size and centromere position (Joachimiak et al., 2001). C-banding techniques (Joachimiak, et al., 2001; Tuna, 2001) have shown that almost all the species analyzed present similar amounts of heterochromatin, mainly telomeric, albeit some small amounts of intercalary heterochromatin were detected. Therefore, distinction between different karyotypes is generally made based on the size of satellites (Armstrong, 1983; Joachimiak et al., 2001).

Send correspondence to Maria Teresa Schifino-Wittmann. Universidade Federal do Rio Grande do Sul, Faculdade de Agronomia, Departamento de Plantas Forrageiras e Agrometeorologia, Caixa Postal 15100, 91501-970 Porto Alegre, RS, Brazil. e-mail: mtschif@ufrgs.br.
In Rio Grande do Sul, Southern Brazil, the genus is represented by the native $B$. auleticus, $B$. brachyanthera, $B$. catharticus, and the exotic B. commutatus and B. mollis species (Longhi, 1977). Among these, the perennial allogamous $B$. auleticus, popularly known as "cevadilha" or "cevadilha vacariana” (Araújo, 1971; Mohrdieck, 1973), occupies an outstanding position as a forage in the native pastures of that State. This species has called the attention of plant breeders and agronomists (Mohrdieck, 1993; Soares, 1999, among others), and some populations have already been characterized by isozyme and RAPD analysis (Yanaka, 2002). Cytological data on this species, however, is scarce. Only isolated chromosome counts in a few plants $(2 \mathrm{n}=42)$ have been performed (Elliott, 1948 and 1949, in Federov, 1969; Bowden and Senn, 1962) and, to our knowledge, no other cytogenetic information on the species has been published.

This paper reports data on chromosome numbers and morphology of 14 natural populations of $B$. auleticus from the State of Rio Grande do Sul.

\section{Material and Methods}

Seeds were collected at several locations of Rio Grande do Sul, Southern Brazil (ca. $33^{\circ}$ to $28^{\circ} \mathrm{S}$ ) (Table 1). Each sample from each collection site was considered as an accession. Seeds from 11 of these accessions were kindly provided by the germplasm bank of EMBRAPA-CPPSul (Empresa Brasileira de Pesquisa Agropecuária - Centro de Pesquisa de Pecuária dos Campos Sul-Brasileiros). 
Table 1 - List of the accessions of Bromus auleticus examined, number of individuals and cells analyzed per accession, and somatic chromosome numbers $(2 \mathrm{n})$.

\begin{tabular}{llccc}
\hline Accession & Collection site & $\begin{array}{c}\text { Number of } \\
\text { individuals }\end{array}$ & $\begin{array}{c}\text { Number } \\
\text { of cells }\end{array}$ & 2n \\
\hline OvGoMgGu 64 & Livramento, RS & 5 & 16 & 42 \\
OvGoMgGu 66 & Livramento, RS & 8 & 17 & 42 \\
OvGoMgGu 69 & Livramento, RS & 7 & 19 & 42 \\
OvGoMgGu 80 & Uruguaiana, RS & 8 & 12 & 42 \\
OvGoMgGu 97 & Itaara, RS & 5 & 12 & 42 \\
GoRg 121 & Júlio de Castilhos, RS & 6 & 21 & 42 \\
GoRg 126 & Vacaria, RS & 3 & 3 & 42 \\
GoOv 59 & Pinheiro Machado, RS & 5 & 16 & 42 \\
GoOv 62 & Dom Pedrito, RS & 8 & 22 & 42 \\
GoLe 110 & Livramento, RS & 10 & 29 & 42 \\
OvGoGu 107 & Cruz Alta, RS & 9 & 20 & 42 \\
Santiago & Santiago, RS & 4 & 10 & 42 \\
Santana Livramento & Santana do Livramento, RS & 7 & 10 & 42 \\
Quaraí & Quaraí, RS & 5 & 13 & 42 \\
\hline
\end{tabular}

a accession from the germplasm bank of EMBRAPA-CPP Sul.

For somatic chromosome counts, seeds were germinated in Petri dishes with moistened filter paper, and the 1$1.5 \mathrm{~mm}$ long roots were pre-treated with a saturated solution of paradichlorobenzene (PDB) for $18-20 \mathrm{~h}$ at $4{ }^{\circ} \mathrm{C}$, fixed in 3:1 ethanol-acetic acid for $24 \mathrm{~h}$, and stored in $70 \%$ ethanol below $0{ }^{\circ} \mathrm{C}$ until required. For slide preparation, root tips were hydrolyzed with $\mathrm{HCl} 1 \mathrm{~N}$ for 10 to 15 min at $60{ }^{\circ} \mathrm{C}$, stained with Feulgen for $c a .2 \mathrm{~h}$, and squashed in a drop of acetic carmine. Semi-permanent slides were examined by light microscopy. Only intact and well-spread metaphases were analyzed. Each root tip was considered as one individual.

\section{Results and Discussion}

All the 220 cells of the 90 analyzed individuals of the 14 accessions presented $2 \mathrm{n}=42$ chromosomes (Table 1, Figure 1). The ploidy level of B. auleticus (hexaploid) is the same as in other native South-American species, such as $B$. bonariensis, B. brevis, B. parodii, B. brachyanthera var. uruguayensis, B. catharticus (Schifino and Winge, 1983; Naranjo, 1985).

Chromosome size ranged from ca. $4 \mu \mathrm{m}$ to ca. $8 \mu \mathrm{m}$, and they were all either metacentric or submetacentric. Detailed karyotypic analyses were not performed, but chromosome morphology was very similar to that reported for several Eurasian and North-American Bromus species (Schulz-Schaeffer and Markarian, 1957; Armstrong, 1983; Joachimiak et al., 2001; Tuna et al., 2001), as well as for the South-American species B. catharticus (Schifino and Winge, 1983; Naranjo, 1985), B. brevis, B. parodii, and B. bonariensis (Naranjo, 1985).

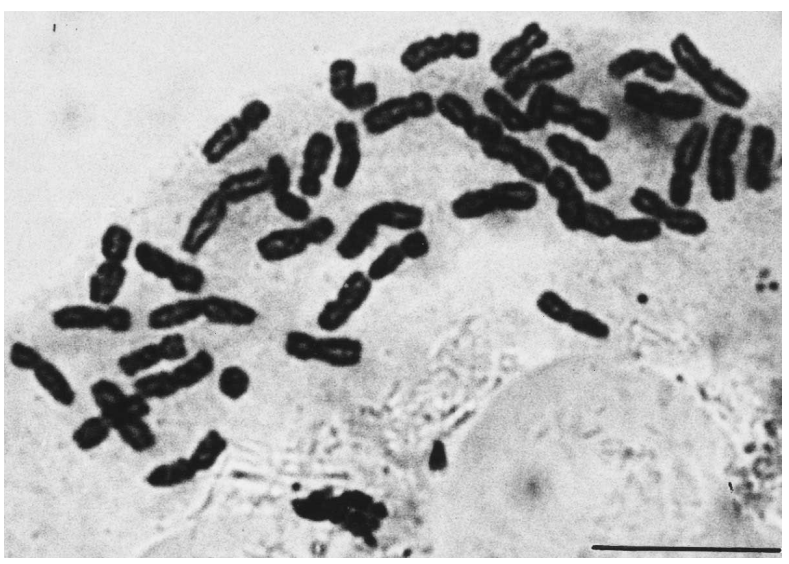

Figure 1 - Metaphase plate of Bromus auleticus $(2 \mathrm{n}=42)$ (one chromosome on the lower left side of the cell is folded). Scale bar equal to $10 \mu \mathrm{m}$.

Up to two satellite-bearing chromosome pairs could be seen in a few cells of some accessions, but in most cells the satellites were very difficult to distinguish. Armstrong (1982) already pointed out the difficulty in detecting satellites when they are small or when the chromosomes are very condensed. Naranjo (1985), reviewing data from the literature, commented that there might be actual differences in the number of satellite-bearing chromosomes (or in the number of these chromosomes expressed) among different Bromus individuals or species, but that the high symmetry and homogeneity of the karyotypes could also make it difficult to detect possible differences.

A pilot FISH (fluorescent in situ hybridization) test performed in one B. auleticus accession (data not shown) suggested the presence of up to fourteen $45 \mathrm{~S}$ rDNA sites. 
Bromus chromosomes are a good material for cytogenetic analysis, regarding for example their size, however the little success obtained so far in detecting variability with conventional staining and $\mathrm{C}$-banding techniques suggests that more advanced techniques should be employed.

\section{Acknowledgments}

The authors thank Conselho Nacional de Desenvolvimento Científico e Tecnológico (CNPq) for the postdoctoral fellowship granted to the G.E.M., and Dr. Klecius Ellera Gomes and MSc José Carlos de Oliveira from EMBRAPA-CPPSul for supplying the seeds.

\section{References}

Araújo AA (1971) Principais gramíneas do Rio Grande do Sul. Sulina, Porto Alegre, $255 \mathrm{pp}$.

Armstrong KC (1982) Hybrids between the tetraploids of Bromus inermis and B. pumpellianus. Can J Bot 60:476-482.

Armstrong KC (1983) The relationship between some Eurasian and American species of Bromus section Pnigma as determined by the karyotypes of some F1 hybrids. Can J Bot 61:700-707.

Bowden WM and Senn HA (1962) Chromosome numbers in 28 grass genera from South America. Can J Bot 40:1115-1124.

Carlson IT and Newell LC (1985) Smooth Bromegrass. In: Heath ME, Barnes RF and Metcalfe DS (eds) Forages. 4th ed. Iowa State University Press, Ames, pp 198-206.

Elliott, FC (1948) Cross-fertility and cytogenetics of selected Bromopsis section Members within the genus Bromus L. Iowa State Coll J Sci 24:44-45 in: Federov AA (1969) Chromosome Numbers of Flowering Plants. Russian Academy of Sciences, Leningrad, $926 \mathrm{pp}$.

Elliott, FC (1949) The cytology and fertility relations of Bromus inermis and some of its relatives. Agron Jour 41:298-303 in: Federov AA (1969) Chromosome Numbers of Flowering Plants. Russian Academy of Sciences, Leningrad, 926 pp.

Federov AA (1969) Chromosome Numbers of Flowering Plants. Russian Academy of Sciences, Leningrad, 926 pp.
Joachimiak A, Kula A, Sliwinska E and Sobieszczanska A (2001) C-banding and nuclear DNA amount in six Bromus species. Acta Biol Cracov Ser Bot 43:105-115.

Longhi, HM (1977) O gênero Bromus L. (Gramineae) no Rio Grande do Sul. In: Trabalhos do XXVI Congresso Nacional de Botânica, Academia Brasileira de Ciências, Rio de Janeiro, pp 333-342.

Mabberley DJ (1997) The Plant-Book. Cambridge University Press, Cambridge, 858 pp.

Mohrdieck KH (1993) Formações campestres do Rio Grande do Sul. In: Federacite (ed), Campo nativo - melhoramento e manejo, Caramurú, Porto Alegre, pp 11-23.

Naranjo CA (1985) Estudios citogeneticos, bioquimicos y sistematicos en algunas especies americanas del genero Bromus (Gramineae). PhD Thesis, Universidade de Buenos Aires, Buenos Aires.

Oja T and Laarmann H (2002) Comparative study of the ploidy series Bromus sterilis, B. diandrus and B. rigidus (Poaceae) based on chromosome numbers, morphology and isozymes. Plant Biol 4:484-491.

Schifino MT and Winge H (1983) Karyotypes and nuclear DNA content of species of the Briza complex and some other genera of Poeae (Gramineae). Rev Bras Genet 6:245-259.

Schulz-Schaeffer J and Markarian D (1957) Cytologische Untersuchungen in der Gattung Bromus L. II. Untersuchungen an Wurzelspitzen zur Klärung der Chromosomenmorphologie bei den Untergattungen Ceratochloa und Bromus. Zeitsch Pflanzenz 37:299-316.

Soares GS (1999) Caracterização agronômica e melhoramento genético de uma população de cevadilha vacariana (Bromus auleticus Trinius ex Nees). MSc Dissertation, Universidade Federal do Rio Grande do Sul, Porto Alegre.

Tuna M, Gill KS and Vogel KP (2001) Karyotype and C-banding patterns of mitotic chromosomes in diploid bromegrass (Bromus riparius Rehm). Crop Sci 41:831-834.

Yanaka FY (2002) Caracterização molecular e isoenzimática de acessos de Bromus auleticus Trinius ex Nees. MSc Dissertation, Universidade Federal do Rio Grande do Sul, Porto Alegre. 